\title{
The Relationship Between the Study Habits and Attitudes and Metacognitive Reading Comprehension Self-Awareness, Reading Comprehension, Reading Attitudes
}

\author{
Aysel Demiroğlu Memiş̧, ${ }^{1 *}$ \& Hülya Kandemir ${ }^{1}$ \\ ${ }^{1}$ Eregli Faculty of Education, Zonguldak Bulent Ecevit University, Zonguldak, Turkey \\ *Correspondence: Faculty of Education, Zonguldak Bulent Ecevit University, Ereğli-Zonguldak, Turkey. Tel: \\ 90-505-319-2122. E-mail: ayselmemis@gmail.com
}

Received: July 11, 2019

Accepted: August 5, $2019 \quad$ Online Published: August 25, 2019

doi:10.5430/wje.v9n4p133

URL: https://doi.org/10.5430/wje.v9n4p133

\begin{abstract}
The aim of the study is to analyze the correlation between study habits and attitudes and metacognitive reading comprehension self-awareness, reading comprehension and reading attitude of fifth-grade students. 313 students (193 female, 188 male) consisted the sample group of the study using relational screening model. SSHA-Survey of Study Habits and Attitudes, Form C", "Metacognitive Reading Comprehension Self-Awareness Scale", "Reading Comprehension" and, "Reading Attitudes Scale" were used. Moreover, students' level of Turkish course success has been identified by their grades from school reports of the first term of fifth grade. As the result of the study, it was found that the study orientation scores of the students were higher than the average and that their study attitudes were higher than their studying habits. There was a mid-scale, positive and significant correlation between the sub-dimensions of their studying attitudes and habits. The levels of correlation between students' success in Turkish course and their study orientation; between their metacognitive awareness of reading comprehension, reading comprehension and studying habits with their studying orientation; between their metacognitive awareness of reading comprehension, reading comprehension and reading attitude with study orientation, and between their metacognitive awareness of reading comprehension and reading attitude with their study attitudes was found to be positive, mid-scale and significant. However, the level of correlation between their metacognitive awareness of reading comprehension and reading comprehension was found to be positive, low-scale and significant.
\end{abstract}

Keywords: study habits, study attitudes, metacognitive reading comprehension self-awareness, reading comprehension, reading attitudes

\section{Introduction}

Process to success is a common research issue not only for Turkey but for many countries in the world. The statuses of students are compared by the international exams performed, measures are tried to be taken for the processes and the education systems of the successful countries are examined. Many studies have revealed that success is related to study skills and habits. By study habits and attitudes, it is meant to be ready for a reaction in a special way to the school activities in and out of school hours and have a certain behavior pattern (as cited in Küçükahmet,1987:2). One of the most important variables of the study habits and attitudes which have an importance for the success of students is reading skills (Orr, 1992; Yıldırım et al., 2000; Uluğ, 2000; Özakpınar, 2002; Price \& Maier, 2007; Crossman, 2011).

A maximal success from a reading process which is probably the most important way of obtaining information is related to the ratio of reading comprehension. In the studies, reading comprehension strategies that help reading comprehension and effective learning at all levels of education, especially metacognitive reading comprehension strategies have been found to be of great importance. Metacognition is essential for a successful cognition, because it allows individuals to better manage their cognitive skills and identify weaknesses that can be corrected by creating new cognitive skills. Encouragement of metacognition begins with creating a perception that metacognition exists and differs from cognition, and creating awareness among students who increase his/her academic achievement. Use of metacognitive strategies increases the ratio of reading comprehension and the students using the strategy have a high 
ratio of reading comprehension. Research studies focus on metacognitive strategies have indicated that less competent students can improve their skills by studying the strategies specified by the successful students (Schraw, 1998; Çakıroğlu and Ataman, 2008; Çöğmen and Saracaloğlu, 2010; Karbalaei, 2011; Kuruyer and Özsoy, 2016). Most research on metacognition is related to the achievement in reading and learning (Van Kraayenoord, 2010). It is possible to say that individuals who have metacognitive reading skills and who know when, where and how to transfer these skills will exhibit a high reading and reading comprehension performance as well as high self-efficacy perception (Kuruyer and Özsoy, 2016). The relationship between metacognition and academic achievement was demonstrated by Landine and Stewart (1998) for the twelfth grade students and by Coutinho (2007) for university students, whereas Cattell (1999) found that teaching metacognitive skills to the fourth grade students significantly affected their reading comprehension levels. Moreover, Van Kraayenoord and Schneider (1999) found that there was a significant relationship between the metacognition and reading achievements of the three and fourth grade students, and Özsoy et al. (2009) found in their studies conducted with the fifth grade students that there was a moderate, positive and significant relationship between the metacognitive knowledge and skill scores and study habits and attitudes of students having an achievement at a high level.

There is also a strong link between the students' reading attitudes and reading comprehension skills (Şeflek Kovacioğlu, 2006; Karabay and Kuşdemir Kayıran, 2010; Tunde-Awe, 2014) and the academic achievement of the Turkish course is increased as the attitude towards reading increases (Başaran and Ateş, 2009; Karabay and Kuşdemir Kayıran, 2010; Aydoğdu, 2012; Baştuğ, 2014). Ürün Karahan and Taşdan (2016) stated that the students 'attitudes and motivation towards reading were high, whereas Tunde - Awe (2014) stated that the students' reading attitudes were low. However, it is stated that reading attitudes decrease as the students' class level increases (İşeri, 2010; Umucu Alpoğuz, 2014; Kolić-Vehovec et al., 2014; Yıldız and Kaman, 2016; Baki, 2017).

In order for the students to be successful in their academic life, they have to determine their own study habits at an early age, which will lead them to success. Studying is an action that we do and have to do in every aspect of our lives. In this age of speed, gaining and assimilating the most permanent information in the shortest time is a necessity of life. Given that the success will be achieved by studying effectively, not by studying hard, students need to have efficient study habits and reading skills to be successful. In the case that proper study habits cannot be determined, and when the text cannot be understood even if they are determined, success cannot be achieved despite studying hard. Okanezi and Braide (2018) have stated that regular reading, which is one of the important factors of study habits, will positively affect the students' academic performance. Bentil et al. (2018) stated in their inventory of study habits adapted and used by them that reading and note-taking are among the sub-headings of the scale together with doing homework, allocating time, concentrating and time management. In the study, it has been emphasized that reading and note-taking and time management have an important contribution to the academic performance, thus teachers should take precautions to increase the academic achievement. Nandhini (2017) considered the factors of study habits as reading and taking notes, concentration, time management, home and school environment, and memory, whereas Fazal et al. (2012) emphasized a significant relationship between time management, reading and note-taking skills and academic achievement. The scale developed by Bliss and Mueller (1986) in order to examine the students' study behaviors consists of general study attitudes and behaviors, reading and note taking techniques, and exam strategies. Akagah (2011) stated that exams, home works, reading and note-taking, concentration, time management were variables that predict study habits. Smith Rotchford (1984) compared the reading achievements with the study orientations. According to the type of school, it was determined that there were significant relationships between the students' reading and study orientation scores and the sub-dimensions of study habits and attitudes. Wonnacott (1989) found a significant, positive but low relationship between the reading, study skills and academic achievement. Mendezabal (2013) stated that inefficient time management, unplanned studying and low concentration, poor reading skills, poor test techniques, failures in informing teachers and asking for help on issues they had difficulty in school were inappropriate study habits. Onwuegbuzie et al. (2001) have stated that study behaviors are discriminatory for high and low course success, note-taking and reading skills among the study behaviors are weak in students and study skills programs should be applied at an early age. Study habits and attitudes were examined by comparing with success (Dilek, 1993; Atılgan, 1998; Arslantaş, 2001; Şener, 2001; Özbey, 2007; Yörük, 2007; Çetin, 2009; Gazioğlu, 2009; Gündüz, 2009; Eren, 2011; Ergene, 2011; Memiş, 2013; Durukan et al.,2015; Yıldız, 2015; Bıyıklı, 2017; Kızılboğa, 2017), learning styles (Ersoy, 2003; Günaydın, 2011; Kaya et al., 2012; Deniz, 2013; Kayacık, 2013; Bayır, 2015; Başbay et al., 2018), parent attitudes (Aydıner, 2004), and sense of self (Güngör, 2010) variables in our country. It has been determined that there are not enough studies on the relationship between study habits and attitudes and reading skills in our country. Therefore, it is thought that the study results will contribute to the field. 
The aim of this study is to investigate the relationship between the fifth grade students' study habits and attitudes and metacognitive reading comprehension self-awareness, reading comprehension and reading attitudes. The problem "Is there a relationship between the fifth grade students' study habits and attitudes and metacognitive reading comprehension self-awareness, reading comprehension and reading attitudes?" was examined and an answer to the following sub-problems was sought:

1. Are metacognitive reading comprehension self-awareness, reading comprehension and reading attitude levels a significant predictor of study habits and attitudes?

2. Is there a significant relationship between the study habits and attitudes, metacognitive reading comprehension self-awareness, reading comprehension and reading attitude levels and Turkish course achievements?

\section{Method}

The study is a correlational survey model which is one of the general survey models. In this model, it is examined whether the variables change together and how an existing change occurs (Karasar, 1995:81-84).

\subsection{Study Population}

Study population consists of 381 students studying in the fifth grade of three public schools in Saray district of Tekirdağ between 2018 and 2019 academic years, with 193 of the students being female and 188 being male. In the study, the whole population was tried to be reached, but 312 students were reached due to missing data and absenteeism. $53.5 \%$ of 312 students are female and $46.5 \%$ are male.

\subsection{Data Collection Tools}

Study data were collected by four different scales. For measuring the students' study habits and attitudes, 'Survey of Study Habits and Attitudes, Form C" was used, which was developed by Brown and Holtzman, translated into Turkish and validated for reliability by Küçükahmet (1987) for the university students, and adapted by Memiş (2005, 2007) for the fifth grade students. There were 52 items and 4 sub-dimensions in SSHA. These 4 sub-dimensions consist of delay avoidance (DA), work methods (WM), teacher approval (TA) and education acceptance (EA) (Brown $\&$ Holtzman, 1967). Every two of the surveys form the total of upper dimension [delay avoidance + work methods $=$ study habits (SH); teacher approval + education acceptance = study attitudes (SA)], the total of the two upper dimensions [study habits + study attitudes $=$ study orientations] form study orientations of the students. The students get max 26 scores for each of the sub-dimensions (DA, WM, TA, EA), for the upper dimensions (SH, SA) they get 52 scores, for the study orientation they get 104 scores.

Metacognitive reading comprehension self-awareness was measured using the "Metacognitive Reading Comprehension Self-Awareness Scale" which was adapted and validated for reliability by Çakıroğlu (2007) for the fifth grade students. The scale consists of 30 items. Each question in the scale was scored as (1), (2), and (3). Accordingly, a minimum score that can be obtained from the scale is 30 and a maximum score is 90 . The scale includes a grading system from the least (1) to the most desirable one (3) for each item, and the student chooses the most appropriate one from these three options for that question.

The levels of reading comprehension were determined by means of 6 inference items and 9 items measuring the information given explicitly in the text in the 15-item test of the "Balloon" text, which was adapted and validated for reliability by Saraç (2010) for the fifth grade students. The balloon text is an informative text consisting of 459 words giving information about the structure of the balloon, its movement system, its types and the places where it is used.

Reading attitude was measured with a Reading Attitude Scale, the validity and reliability test of which was performed by Çakıroğlu and Palancı (2015). The scale is likert type and 4 point is given for very happy, 3 point is given for a little bit happy, 2 point is given for a little bit unhappy and 1 point is given for a very unhappy face expression. The total scores obtained from each sub-dimension range between 10 and 40, and the total scores from the entire scale are between 20 and 80 points.

Students' Turkish course achievements was determined by the grades at the end of semester obtained by evaluating the basic language skills of listening, speaking, reading, writing during the fall semester of 2018-2019 academic years. 


\subsection{Data Analysis}

Data of the study carried out by the researcher during the fall semester of 2018-2019 academic years were analyzed using the SPSS for Windows 21.0 program. In order to be analyzed according to suitable analysis techniques, firstly, it was examined whether it showed a normal distribution or not, and the significance levels of $p<0.01$ and $p<0.05$ were used in statistical analysis and interpretation. The relationship between the variables was calculated using Pearson Moment Correlation Coefficient and values between 0.70-1.00 were considered as a high relationship, values between $0.70-0.30$ were considered as a moderate relationship, and values between $0.30-0.00$ were considered as a low relationship (Büyüköztürk, 2018, p. 32). Mahalanobis distance values were calculated in multiple linear regression analysis and in the analysis for extreme values, data of 1 student was removed from the file and the study was continued with 312 students. In the process of examining whether there is a multicollinearity problem in the data layout, firstly, bivariate relationships between independent variables were examined and the highest value was found to be $.39(<.80)$. At the same time, it was determined that the tolerance values were above .80 (not less than .20 ), the variance inflation factor (VIF) values were maximum 1.247 (not higher than 10), and the status index values were maximum 26.961 (not higher than 30) and there was no multicollinearity.

\section{Results}

Table 1 shows the study habits and attitudes of the fifth grade students.

Table 1. Study Habits and Attitudes of the Fifth Grade Students

\begin{tabular}{lcc}
\hline & M & S \\
\hline Delay Avoidance (DA) & 16.02 & 5.62 \\
Work Methods (WM) & 19.03 & 5.26 \\
Study Habits (SH) & 35.05 & 9.85 \\
Teacher Approval (TA) & 18.74 & 5.45 \\
Education Acceptance (EA) & 17.70 & 4.93 \\
Study Attitudes (SA) & 36.44 & 9.28 \\
Study Orientation (SO) & 71.49 & 17.52 \\
\hline
\end{tabular}

When the arithmetic means are analyzed according to the two sub-dimensions of the study orientation, it is seen that the scores (36.44) of the students in their study attitudes are higher than their study habits scores (35.05). In the sub-dimensions of both dimensions, it was determined that the students had the highest arithmetic mean in study methods (19.03) and the lowest arithmetic mean in delay avoidance (16.02). The arithmetic mean of the study orientation scores of the students was 71.79. The relationship between the study habits and attitudes of the students is given in Table 2 .

Table 2. The Relationship Between Study Habits and Attitudes of Students

\begin{tabular}{lllll}
\hline & WM & TA & EA & SA \\
\hline DA & $.64^{* *}$ & $.39^{* *}$ & $.54^{* *}$ & \\
WM & & $.64^{* *}$ & $.64^{* *}$ & \\
TA & & & $.60^{* *}$ & \\
SH & & & & $.68^{* *}$ \\
\hline
\end{tabular}

${ }^{*} \mathrm{p}<0.01$

According to the results, there is a high relationship between the study habits and attitudes $(0.68)$. There is a marked moderate, positive and significant relationship between the delay avoidance and study methods $(0.64)$ and the teacher approval and education acceptance. There is a moderate, positive and significant relationship between the study methods and teacher approval (0.64) and education acceptance (0.64).

3.1 Metacognitive Reading Comprehension Self-Awareness, Reading Comprehension and Reading Attitude Levels as Predictors of Study Habits and Attitudes

Results for the metacognitive reading comprehension self-awareness, reading comprehension and reading attitude levels as the predictors of study habits and attitudes of the students are provided in Table 3. 
Table 3. Results of Multiple Regression Analysis

\begin{tabular}{|c|c|c|c|c|c|c|c|c|}
\hline & SH & SA & $\mathrm{SO}$ & MRCSA & $\mathrm{RC}$ & Tolerance & VIF & Status Index \\
\hline Metacognitive Reading & & & & & & & & \\
\hline $\begin{array}{l}\text { Comprehension Self-Awareness } \\
\text { (MRCSA) }\end{array}$ & $.372 *$ & $.366^{*}$ & $.403^{*}$ & - & - & .802 & 1.247 & 6.844 \\
\hline Reading Comprehension (RC) & $.314^{*}$ & $.257^{*}$ & $.313^{*}$ & $.390 *$ & - & .848 & 1.180 & 19.855 \\
\hline Reading Attitude (RA) & $.419^{*}$ & $.408^{*}$ & $.452 *$ & $.252 *$ & .102 & .937 & 1.068 & 26.961 \\
\hline
\end{tabular}
$* \mathrm{p}<0,01$

When Table 3 was examined, it was determined that the highest bivariate relationships between the metacognitive reading comprehension self-awareness, reading comprehension and reading attitude levels were found to be 0.39 $(<.80)$. At the same time, it was determined that the tolerance values were above .80 (not less than .20 ), the variance inflation factor (VIF) values were maximum 1.247 (not higher than 10), and the status index values were maximum 26.961 (not higher than 30) and there was no multicollinearity.

Table 4. Results of Standard Multiple Regression Analysis for Predicting the Study Habits

\begin{tabular}{lccccccc}
\hline & $\mathrm{B}$ & $\mathrm{SE}$ & $\beta$ & $\mathrm{t}$ & $\mathrm{p}$ & Bivariate $\mathrm{r}$ & Partial $\mathrm{r}$ \\
\hline $\begin{array}{l}\text { Constant } \\
\text { Metacognitive Reading }\end{array}$ & -16.088 & 5.148 & - & -3.125 & .002 & - & - \\
$\begin{array}{l}\text { Comprehension } \\
\text { Self-Awareness }\end{array}$ & 0.270 & 0.070 & 0.208 & 3.860 & .000 & 0.372 & 0.215 \\
$\begin{array}{l}\text { Reading Comprehension } \\
\text { Reading Attitude }\end{array}$ & 0.098 & 0.026 & 0.198 & 3.775 & .000 & 0.314 & 0.210 \\
\hline \multicolumn{7}{c}{$\mathrm{R}=0.533$} & $\mathrm{R}^{2}=0.284$ \\
& 0.422 & 0.061 & 6.957 & .000 & 0.419 & 0.369 \\
\hline
\end{tabular}

When the bivariate and partial relationships between the predictive variables and study habits are examined, it is seen that there is a positive and moderate relationship between the metacognitive reading comprehension awareness and study habits $(\mathrm{r}=0.37)$, and when the other variables are checked, the relationship between two variables is found to be $r=0.21$. There is a positive and moderate relationship between the reading comprehension and study habits ( $\mathrm{r}=$ 0.31 ), and when the other variables are checked, the relationship between two variables is $\mathrm{r}=0.21$, similarly to that of the other variable. The relationship between the reading attitude and study habits is higher as compared to the other variables $(\mathrm{r}=0.42)$, and when the other two variables are checked, it is seen that the relationship is positive and moderate $(\mathrm{r}=0.37)$. These three variables provide a moderate, positive and significant relationship with the study habits $\left(\mathrm{R}=0.533 \mathrm{R}^{2}=0.284 \mathrm{p}<0.05\right)$ and account for $28 \%$ of the total variance. According to the standardized regression coefficient $(\beta)$, the order of importance of variables on the study habits is as follows; reading attitude, metacognitive reading comprehension self-awareness and reading comprehension. When the t-test results regarding the significance of the regression coefficients are examined, it is seen that all three variables are significant predictors of the study habits.

Table 5. Results of Standard Multiple Regression Analysis for Predicting the Study Attitudes

\begin{tabular}{lccccccc}
\hline & $\mathrm{B}$ & $\mathrm{SE}$ & $\beta$ & $\mathrm{t}$ & $\mathrm{p}$ & Bivariate $\mathrm{r}$ & Partial r \\
\hline $\begin{array}{l}\text { Constant } \\
\text { Metacognitive Reading }\end{array}$ & -11.139 & 4.951 & - & -2.250 & .025 & - & - \\
$\begin{array}{l}\text { Comprehension } \\
\text { Self-Awareness }\end{array}$ & 0.280 & 0.067 & 0.229 & 4.174 & .000 & 0.366 & 0.231 \\
$\begin{array}{l}\text { Reading Comprehension } \\
\text { Reading Attitude }\end{array}$ & 0.062 & 0.025 & 0.133 & 2.489 & .013 & 0.257 & 0.140 \\
& 0.386 & 0.058 & 0.336 & 6.620 & .000 & 0.408 & 0.353 \\
\hline & $\mathrm{R}=0.505$ & $\mathrm{R}^{2}=0.255$ \\
& $\mathrm{~F}(3,308)=35.152 \quad \mathrm{p}=0.000$ & & & \\
\hline
\end{tabular}


When the bivariate and partial relationships between the predictive variables and the study attitudes are examined, it is seen that there is a positive and moderate relationship between the metacognitive reading comprehension self-awareness and study attitudes $(\mathrm{r}=0.37)$, and when the other variables are checked, the relationship between two variables is found to be $r=0.23$. There is a positive and low relationship between the reading comprehension and study attitudes $(\mathrm{r}=0.26)$, and when the other variables are checked, the relationship between two variables is found to be $r=0.14$. The relationship between the reading attitudes and study attitudes is higher as compared to the other variables $(\mathrm{r}=0.41)$, and when the other two variables are checked, a positive and moderate relationship $(\mathrm{r}=0.35)$ is found. These three variables provide a moderate, positive and significant relationship with the study attitudes $\left(\mathrm{R}=0.505 \mathrm{R}^{2}=0.255 \mathrm{p}<0.05\right)$ and account for $25 \%$ of the total variance. According to the standardized regression coefficient $(\beta)$, the order of importance of variables on the study attitudes is as follows; reading attitude, metacognitive reading comprehension self-awareness and reading comprehension. When the t-test results regarding the significance of the regression coefficients are examined, it is seen that all three variables are significant predictors of the study attitudes.

Table 6. Results of Standard Multiple Regression Analysis for Predicting Study Orientation

\begin{tabular}{lccccccc}
\hline & $\mathrm{B}$ & $\mathrm{SE}$ & $\beta$ & $\mathrm{t}$ & $\mathrm{p}$ & Bivariate $\mathrm{r}$ & Partial $\mathrm{r}$ \\
\hline Constant & -27.227 & 8.915 & - & -3.054 & .002 & - & - \\
Metacognitive reading & 0.550 & 0.121 & 0.238 & 4.547 & .000 & 0.403 & 0.251 \\
comprehension self-awareness & & & & & \\
Reading comprehension & 0.159 & 0.045 & 0.182 & 3.562 & .000 & 0.313 & 0.199 \\
Reading attitude & 0.808 & 0.105 & 0.373 & 7.694 & .000 & 0.452 & 0.402 \\
\hline \multicolumn{7}{c}{$\mathrm{R}=0.567 \mathrm{R}^{2}=0.321$} \\
& $\mathrm{~F}(3,308)=48.611 \quad \mathrm{p}=0.000$ & & \\
\hline
\end{tabular}

When the bivariate and partial relationships between the predictive variables and the study orientation are examined, it is seen that there is a positive and moderate relationship between the metacognitive reading comprehension self-awareness and the study orientation $(\mathrm{r}=0.40)$, and when the other variables are checked the relationship between two variables is found to be $r=0.25$. There is a positive and moderate relationship between the reading comprehension and study orientation $(\mathrm{r}=0.31)$, and when the other variables are checked, the relationship between two variables is found to be $r=0.20$. The relationship between the reading attitude and study orientation is higher as compared to the other variables $(\mathrm{r}=0.45)$ and when the other two variables are checked, there is found a positive and moderate relationship $(\mathrm{r}=0.40)$. These three variables provide a moderate, positive and significant relationship with the study orientation $\left(\mathrm{R}=0.567 \mathrm{R}^{2}=0.321 \mathrm{p}<0.05\right)$ and account for $32 \%$ of the total variance. According to the standardized regression coefficient $(\beta)$, the order of importance of variables on the study orientation is as follows; reading attitude, metacognitive reading comprehension self-awareness and reading comprehension. When the t-test results regarding the significance of the regression coefficients are examined, it is seen that all three variables are significant predictors of the study orientation.

3.2 The relationship between the Study Habits and Attitudes, Metacognitive Reading Comprehension Self-Awareness, Reading Comprehension, Reading Attitudes of the Fifth Grade Students and Their Achievement Levels

When the relationship between the study habits and attitudes, metacognitive reading comprehension self-awareness, reading comprehension, reading attitudes of the students and their Turkish course achievements was examined, the results in Table 7 were obtained.

Table 7. The Relationship between Study Habits and Attitudes, Metacognitive Reading Comprehension Self-Awareness, Reading Comprehension, Reading Attitude and Turkish Course Achievement

\begin{tabular}{lcccccccccc}
\hline & DA & WM & SH & TA & EA & SA & SO & MRCSA & RC & RA \\
\hline $\begin{array}{l}\text { Turkish Course } \\
\text { Achievement }\end{array}$ & $.47^{*}$ & $.52^{*}$ & $.55^{*}$ & $.59^{*}$ & $.35^{*}$ & $.43^{*}$ & $.53^{*}$ & $.44^{*}$ & $.59^{*}$ & $.20^{*}$ \\
\hline 0.01 & & & & & & & & & &
\end{tabular}

There is a moderate, positive and significant relationship between the students' Turkish course achievement and the study orientation in the sample of 312 people (0.53). The relationship between the study habits and the achievement $(0.55)$ is higher than the study attitudes $(0.43)$. Among the sub-dimensions, it is seen that the teacher approval, which 
is a sub-dimension of the study attitudes, has the highest relationship with the achievement (0.59), whereas the education acceptance has the lowest relationship (0.35) in the same sub-dimension. It is noticed that the metacognitive reading comprehension self-awareness $(0.44)$ and reading comprehension $(0.59)$ have a moderate, positive and significant relationship with the achievement, whereas there is a low, positive and significant relationship with the reading attitude $(0.20)$.

\section{Discussion}

The study orientation scores of the students are above the average and their study attitudes are higher than their study habits. Students took the highest scores in the study methods and the lowest scores in the delay avoidance. While students have a positive attitude towards teacher approval and education acceptance, they have a lower average than the others in the delay avoidance that measures their study and homework procrastination behaviors. The results are similar to Demiroğlu Memiş (2007) and Memiş (2013). Arslantaş (2001) stated that students had "moderately" efficient study habits and Yiğit (2014) stated that they had highly efficient study habits, whereas Brown (1941), Barrilleaux (1972), Küçükahmet (1987), Tümkaya and Bal (2006), Mendezabal (2013), and Lalrintluangi (2018) stated in their studies that the participants did not have an appropriate and expected study habits and attitudes. Tulum (2001) concluded that the scores for the study habits of the nursing students were higher than their study attitudes, whereas Durukan et al. (2015) concluded that the prospective teachers had low study habits. In the study conducted by Rana and Kausar (2011) with Pakistani and British students of $10^{\text {th }}$ grade between the ages of 14-16, it was stated that the study habits of the British students were significantly higher than the Pakistani students and there was no significant difference between their academic performances.

There are moderate, positive and significant relationships between the sub-dimensions of the study habits and attitudes of the students. Similar results were obtained in the study conducted by Memiş (2013) with the fifth grade students and in the study conducted by Küçükahmet (1987) with the university students.

There is a positive, moderate and significant relationship between the metacognitive reading comprehension self-awareness, reading comprehension, reading attitude and study habits. The relationship between the reading attitude and study habits is higher as compared to other variables. These three variables provide a moderate, positive and significant relationship with the study habits. The order of importance of variables on the study habits is as follows; reading attitude, metacognitive reading comprehension self-awareness and reading comprehension. It is seen that all three variables are significant predictors of the study habits.

There is a positive, moderate and significant relationship between the metacognitive reading comprehension self-awareness, reading attitude and the study attitudes, whereas there is a positive and low relationship with the reading comprehension. These three variables provide a positive, moderate and significant relationship with the study attitudes. The order of importance of variables on the study attitudes is as follows; reading attitude, metacognitive reading comprehension self-awareness and reading comprehension, and it is seen that all three variables are significant predictors of the study attitudes.

There is a positive, moderate and significant relationship between the metacognitive reading comprehension self-awareness, reading comprehension, reading attitude and the study orientation. These three variables provide a moderate, positive and significant relationship with the study orientation and account for $32 \%$ of the total variance. The order of importance of variables on the study orientation is as follows; reading attitude, metacognitive reading comprehension self-awareness and reading comprehension. It is seen that all three variables are significant predictors of the study orientation.

There is a moderate, positive and significant relationship between the Turkish course achievements and study orientations of the students. The relationship between the study habits and achievement is higher than the study attitudes. Study attitudes have the highest relationship with the achievement, whereas the education acceptance has the lowest relationship with the achievement. Metacognitive reading comprehension self-awareness, and reading comprehension have a moderate, positive and significant relationship with the achievement, whereas there was a positive, low and significant relationship with the reading attitude. There was seen a positive relationship between Turkish course achievement and the study habits in the studies of Çetin (2009), Bayır (2015) and Bıyıklı (2017). Memiş (2013) stated that Turkish course achievement was the predictor of the study habits and attitudes of the male students. Similar to the study, Ahmann and Glock (1957), Cavanaugh (1982), Koivo (1982), Gonzales (1984), Clark-Thayer (1987), Snodgrass (1989), Wonnacott (1989), Yeh (1990), Agnew et al. (1993), Blumner and Richards (1997), Al-Hilawani and Sartawi (1997), Carter (1999), Okpala et al. (2000), Gettinger and Seibert (2002), Yip and Chung (2005), Akagah (2011), Singh (2011), Demir et al. (2012), Memiş (2013), Durukan et al. (2015), Del Villar et 
al. (2016), Kızılboğa (2017), Nandhini (2017), Numan and Syeda (2017), Sakirudeen and Sanni (2017), Bentil et al. (2018), Lalrintluangi (2018) determined that the academic achievements of the students increased as the level of effective use of study methods. Murray and Wren (2003) stated that there was a low and significant relationship between only the sub-dimension of teacher approval and the academic average. McDougle (1989) has stated that the four sub-dimensions of SSHA are not the correct predictors of the academic achievement, and the most notable relationship is between the sub-dimensions of study methods and teacher approval, and sub-dimensions of mathematics and study methods, and the spelling courses. As a result of the study conducted by Rana and Kausar (2011) in which they intended to compare the study habits and academic performances of the Pakistani and British students of $10^{\text {th }}$ grade between the ages of 14-16, it was stated that the study habits of the British students were significantly higher than the Pakistani students, and there was no significant difference between their academic performances. Sallabaş (2008) found a positive and moderate relationship between the students' academic achievement level and reading comprehension skills, but determined a low relationship between their academic achievements and reading attitudes. Başaran and Akyol (2009) concluded that "the academic achievement displayed in Turkish courses has no significant effect on the attitude developed against both narrative and informative texts". The study results of Baştuğ (2014) significantly predicted the reading attitude and reading comprehension achievement in terms of the relationship between the reading attitude, reading comprehension and academic achievement. Eskiyurt et al. (2016), Turhan and Özer (2017) found no statistically significant relationship when they examined the relationship between the metacognitive reading comprehension self-awareness and academic achievement scores.

\section{Conclusions}

The aim of this study is to investigate the relationship between the fifth grade students' study habits and attitudes and metacognitive reading comprehension self-awareness, reading comprehension and reading attitudes. Two important conclusions can be drawn from this research study. First, there is a positive, moderate and significant relationship between the metacognitive reading comprehension self-awareness, reading comprehension, reading attitude and the study orientation. The order of importance of variables on the study orientation is as follows; reading attitude, metacognitive reading comprehension self-awareness and reading comprehension. It is seen that all three variables are significant predictors of the study orientation. Second, there is a moderate, positive and significant relationship between the Turkish course achievements and study habits and attitudes of the students. These results demonstrate that sudy habits and attitudes can be considered critical features for metacognitive reading comprehension self-awareness, reading comprehension and reading attitudes.

\section{Recommendations}

School-family cooperation may have a positive impact on study habits and attitudes. Thus, future researchers can examine the effect of school-family cooperation on study habits and attitudes, metacognitive reading comprehension self-awareness, reading comprehension and reading attitude. Factors affecting variables can be examined through studies at different levels of education.

\section{Acknowledgements}

This study was completed as a Master Thesis at the Zonguldak Bülent Ecevit University, Turkey under the guidance of Dr. Aysel Demiroğlu Memiş

\section{References}

Agnew, N. C., Slate, J. R., Jones, C. H., \& Agnew, D. M. (1993). Academic behaviors as a function of academic achievement, locus of control, and motivational orientation. NACTA J, 37(2), 24-27.

Ahmann, J. S., \& Glock, M. D. (1957). The utility of study habits and attitudes inventory in a college reading program. The Journal of Educational Research, 51(4), 297-303. https://doi.org/10.1080/00220671.1957.10882470

Akagah, F. A. (2011). Influence of study habits on academic performance of junior high school students in the Gomoa West District (Master's thesis). University of Education, Winneba, Gana.

Al-Hilawani, Y., \& Sartawi, A. (1997). Study skills and habits of female university students. College Student Journal, 31(3), 537-544. 
Arslantaş, M. (2001). Ortaöğretim öğrencilerinin ders çalı̧̧ma alı̧̧kanlıkları (Diyarbakır örneği) (Master's thesis). Dicle Üniversitesi/Sosyal Bilimler Enstitüsü, Diyarbakır.

Atılgan, M. (1998). Üniversite ögrrencilerinin ders çalışma alışkanlıklart ile akademik başarılarının karşılaştırılması (Gaziantep üniversitesi ögrencileri üzerine bir araştırma) (Master's thesis). Gaziantep Üniversitesi/Sosyal Bilimler Enstitüsü, Gaziantep.

Aydıner, A. A. (2004). 13 ve 16 yaşlarındaki öğrencilerin ana-baba tutumlarını algılamaları ile çalışma alışkanlıkları ve okul başarıları arasındaki ilişki (Master's thesis). Dokuz Eylül Üniversitesi/Eğitim Bilimleri Enstitüsü, İzmir.

Aydoğdu, Ö. (2012). Investigating the correlation between reading attitudes and academic success of elementary students with structural equation modelling. Uluslararası Sosyal Bilimler Eğitimi Dergisi, 2(1), 62-74.

Baki, Y. (2017). 6, 7 ve 8. sınıf öğrencilerinin okumaya yönelik tutumlarının çeşitli değişkenler açısından incelenmesi. Elektronik Sosyal Bilimler Dergisi, 16(63), 1166-1186. https://doi.org/10.17755/esosder.289915

Barrilleaux, S. P. (1972). Freshmen study habits and attitudes. Montgomery Coll.: Rockville, Md. Retrieved from https://files.eric.ed.gov/fulltext/ ED063916.pdf

Başaran, M., \& Akyol, H. (2009). Okuduğunu anlama ve metne karşı geliştirilen tutum üzerinde metnin bilgi verici veya hikâye edici olmasının etkisi. Uşak Üniversitesi Sosyal Bilimler Dergisi, 2(1), 11-23. https://doi.org/10.12780/ UUSBD41

Başaran, M., \& Ateş, S. (2009). İlköğretim beşinci sınıf öğrencilerinin okumaya ilişkin tutumlarının incelenmesi. Gazi Eğitim Fakültesi Dergisi, 29(1), 73-92.

Başbay, A., Bıyıklı, C., \& Demir, E. K. (2018). Öğrenme stilleri ile ders çalışma alışkanlıklarının incelenmesi. İlkögretim Online, 17(2), 848-863. https://doi.org/10.17051/ilkonline.2018.419316

Baştuğ, M. (2014). The structural relationship of reading attitude, reading comprehension and academic achievement. International J. Soc. Sci., \& Education, 4(4), 931-946.

Bayır, Z. (2015). Üstün zekâlı öğrencilerin öğrenme stilleri ile ders çalışma alışkanlıkları arasındaki ilişkinin çeşitli değişkenler açısından incelenmesi (Master's thesis). Marmara Üniversitesi/Eğitim Bilimleri Enstitüsü, İstanbul.

Bentil, J., Esia-Donkoh, K., \& Ghanney, R. A. (2018). Study habits of students: keys to good academic performance in public junior high schools in the Ekumfi District of Ghana. International Journal of Quantitative and Qualitative Research Methods, 6(3), 10-23.

Bıyıklı, C. (2017). Ortaokul öğrencilerinin Türkçe dersi akademik başarıları ile ders çalışma alışkanlıkları arasındaki ilişki. Pamukkale Üniversitesi Eğitim Fakültesi Dergisi, 42, 59-73. https://doi.org/10.9779/PUJE776

Bliss, L. B., \& Mueller, R. (1986). An instrument for the assessment of study behaviors of college students. Presented at the Annual Meeting of the American Educational Research Association, San Francisco.

Blumner, H. N., \& Richards, H. C. (1997). Study habits and academic achievement of engineering students. The Journal of Engineering Education, 86(2), 125-132. https://doi.org/10.1002/j.2168-9830.1997.tb00275.x

Brown, W. F., \& Holtzman, W. H. (1967). Survey of study habits and attitudes manual form $C$ and form H. New York: The Psychological Corporation.

Brown, W. (1941). The study habits of failing and successful students in the first two years of college. The Journal of Experimental Education, 9(3), 205-208. https://doi.org/10.1080/00220973.1941.11010208

Büyüköztürk, Ş. (2018). Sosyal bilimler için veri analizi el kitabı. Ankara: Pegem. https://doi.org/10.14527/9789756802748

Carter, D. D. G. (1999). The relationship of study habits, attitude, and motivation to academic achievement in a selected course of study at an historically black university (Doctoral dissertation). Morgan State University, Maryland (UMI Number: 9945902).

Cattell, M. (1999). A study of the effects of metacognition on reading comprehension (Master's thesis). San Diego State University, California.

Cavanaugh, R. (1982). Survey of student study habits and attitudes toward school (Doctoral dissertation). The University of Iowa, Iowa. (UMI Number: 8310038). Retrieved from https://elibrary.ru/item.asp?id=7381049 
Clark-Thayer, S. (1987). The relationship of the knowledge of student perceived learning style preferences, and study habits and attitudes to achievement of college freshmen in a small urban university (Doctoral dissertation). Boston University, Boston (UMI Number: 8716075).

Coutinho, S. A. (2007). The relationship between goals, metacognition, and academic success. Educate, 7(1), 39-47.

Crossman, A. (2011). Study Smart, Study Less: Earn Better Grades and Higher Test Scores, Learn Study Habits That Get Fast Results, and Discover Your Study Persona. Berkeley: Ten Speed.

Çakıroğlu, A. (2007). Üstbilişsel strateji kullanımının okuduğunu anlama düzeyi düşük öğrencilerde erişi artırımına etkisi (Doctoral dissertation). Gazi Üniversitesi/Eğitim Bilimleri Enstitüsü, Ankara.

Çakıroğlu, A., \& Ataman, A. (2008). Üstbilişsel strateji öğretiminin okuduğunu anlama başarı düzeyi düşük öğrencilerde erişi artırımına etkisi. Sakarya Üniversitesi Ĕ̆itim Fakültesi Dergisi, 0(16), 1-13.

Çakıroğlu, O., \& Palanc1, M. (2015). Okuma tutum ölçeği: geçerlik ve güvenirlik çalışması. International Journal of Human Sciences, 12(1), 1143-1156. https://doi.org/10.14687/ijhs.v12i1.3248

Çetin, B. (2009). Çalışma alışkanlıkları ölçeğinin ilköğretim 4. sınıf öğrencilerinin akademik başarısını yordaması. Ilköğretim Online, 8(1), 212-223.

Çöğmen, S., \& Saracaloğlu, A. S. (2010). Üst bilişsel okuma stratejileri ölçeği'nin Türkçeye uyarlama çalışmaları. Pamukkale Üniversitesi Ĕ̈itim Fakültesi Dergisi, 28, 91-99.

Del Villar, J. R. B., Gabon, S. S., \& Danuco, V. N. T. (2016). Study behaviors: their influence on students' academic performance. http://dx.doi.org/10.2139/ssrn.3027805

Demir, S., Kılınç, M., \& Doğan, A. (2012). The effect of curriculum for developing efficient studying skills on academic achievements and studying skills of learners. International Electronic Journal of Elementary Education, 4(3), 427-440. Retrieved from https://files.eric.ed.gov/fulltext/EJ1068605.pdf

Demiroğlu Memiş, A. (2007). Öğrencilerin çalışma oryantasyonlarını etkileyen demografik faktörler. Türk Eğitim Bilimleri Dergisi, 5(2), 291-321.

Deniz, S. (2013). Analysis of study habits and learning styles in university students. Kastamonu Eğitim Dergisi, 21(1), 287-302.

Dilek, N. (1993). Askeri lise öğrencilerinin ortaokul ve lisedeki ders çalışma alışkanlıkları ve akademik başarılarının karşılaş̧tırılması (Master's thesis). Marmara Üniversitesi/Sosyal Bilimler Enstitüsü, İstanbul.

Durukan, Ü. G., Batman, D., \& Yiğit, N. (2015). Öğretmen adaylarının ders çalışma alışkanlıkları. İnönü Üniversitesi Eğitim Fakültesi Dergisi, 16(1), 63-80. https://doi.org/10.17679/iuefd.16101104

Eren, O. (2011). İlköğretim 6., 7. ve 8. sinıf öğrencilerinin ders çalışma alışkanlıklart ile fen ve teknoloji dersi akademik başarıları arasındaki ilişski (Master's thesis). Ankara Üniversitesi/Eğitim Bilimleri Enstitüsü, Ankara.

Ergene, T. (2011). The relationships among test anxiety, study habits, achievement, motivation, and academic performance among Turkish high school students. Ĕgitim ve Bilim, 36(160), 320-330.

Ersoy, S. (2003). Illköğretim 6, 7, 8. sinıf ingilizce dersindeki başarılarına göre öğrenme stilleri ve çalışma alışkanlıklarının incelenmesi (Master's thesis). Selçuk Üniversitesi/Sosyal Bilimler Enstitüsü, Konya. Retrieved from https://tez.yok.gov.tr/UlusalTezMerkezi/

Eskiyurt, R., Özkan, B., Deliduman, C., \& Abbak, R. M. (2016). Hemşirelik öğrencilerinin üstbilişsel okuduğunu anlama farkındalığının araştırılması. MAKÜ Sag. Bil. Enst. Dergisi, 4(2), 50-60.

Fazal, S., Hussain, S., Majoka, M. I., \& Masood, S. (2012). The role of study skills in academic achievement of students a closer focus on gender. Pakistan Journal of Psychological Research, 27(1), 37-51.

Gazioğlu, G. (2009). Öğrencilerin çalışma alışkanlıklarının fizik dersi akademik başarıları ile ilişskisinin belirlenmesi (Master's thesis). Gazi Üniversitesi/Eğitim Bilimleri Enstitüsü, Ankara.

Gettinger, M., \& Seibert, J. K. (2002). Contributions of study skills to academic competence. School Psychology Review, 31(3), 350-365.

Gonzales, T. M. (1984). Locus of control and study habits-attitudes scales as predictor of academic achievement of specially admitted (EOP) Hispanic university student (Doctoral Dissertation). University of Washington, Seattle (UMI Number: 8419141). 
Günaydın, F. (2011). İlköğretim 4. ve 5. slnıf ögrencilerinin öğrenme stilleri ile ders çalışma alışkanlıkları arasındaki ilişskinin incelenmesi (Master's thesis). Marmara Üniversitesi/Eğitim Bilimleri Enstitüsü, İstanbul.

Gündüz, G. A. (2009). Merkezi ve kırsal bölgelerde yaşayan ilköğretim okulu ikinci kademe öğrencilerinin çalışma alışkanlıkları, akademik başarlları, okul türleri arasındaki ilişkinin incelenmesi (Master's thesis). Ankara Üniversitesi/Eğitim Bilimleri Enstitüsü, Ankara.

Güngör, G. (2010). Illköğretim düzeyindeki öğrencilerin benlik kavramlarının ve çalışma alışkanlıklarının değerlendirilmesi (Master’s thesis). Gazi Üniversitesi/Eğitim Bilimleri Enstitüsü, Ankara.

İşeri, K. (2010). İlköğretim ikinci kademe öğrencilerinin okuma tutumlarının incelenmesi. Uluslararası İnsan Bilimleri Dergisi, 7(2), 468-487.

Karabay, A., \& Kuşdemir Kayıran, B. (2010). İlköğretim beşinci sınıf öğrencilerinin okuduğunu anlama becerileri ve okumaya ilişkin tutumları arasındaki ilişki. Çukurova Üniversitesi Eğitim Fakültesi Dergisi, 3(38), 110-117.

Karbalaei, A. (2011). Metacognition and reading comprehension. Íkala, 16(28).

Kaya, A., Bozaslan, H., \& Fırat Durdukoca, Ş. (2012). Öğretmen adaylarının öğrenme stilleri ile ders çalışma alışkanlıkları arasındaki ilişkinin incelenmesi. Elektronik Sosyal Bilimler Dergisi, 11(41), 131-146.

Kayacık, E. (2013). Öğrencilerin kolb öğrenme stillerine göre çalışma alışkanlıkları, ödev yapma motivasyonları ve stilleri üzerine bir çalışma (Master's thesis). Eskişehir Osmangazi Üniversitesi/Eğitim Bilimleri Enstitüsü, Eskişehir.

Kızılboğa, M. (2017). 7. Sinıf öğrencilerinin çalışma alışkanlıkları ve tutumlarının akademik başarı ile ilişkisi (Master's thesis). Toros Üniversitesi/Sosyal Bilimler Enstitüsü, Mersin.

Kolić-Vehovec, S., Rončević Zubković, B., \& Pahljina-Reinić, R. (2014). Development of metacognitive knowledge of reading strategies and attitudes toward reading in early adolescence: the effect on reading comprehension. Psychological Topics, 23(1), 77-98.

Kuruyer, H. G., \& Özsoy, G. (2016). İyi ve zayıf okuyucuların üstbilişsel okuma becerilerinin incelenmesi: bir durum çalışması. Kastamonu Ĕgitim Dergisi, 24(2), 771-788.

Küçükahmet, L. (1987). Öğrencilerin çalışma alışkanlıkları ve tutumları (üniversite öğrencileri üzerine bir araştırma). Ankara Üniversitesi Eğitim Bilimleri Fakültesi Yayınları No:153.

Lalrintluangi (2018). Study habits and academics achievement of under graduate students in Aizawl City. IOSR Journal Of Humanities And Social Science (IOSR-JHSS), 23(7), 1-5.

Landine, J., \& Stewart, J. (1998). Relationship between metacognition, motivation, locus of control, self-efficacy, and academic achievement. Canadian Journal of Counselling, 32(3), 200-212.

McDougle, K. O. (1989). Predicting academic achievement from study skills habits among Upward Bound students (Doctoral dissertation). University of North Texas, Denton, Texas (UMI Nu8921241).

Memiş, A. (2005). Öğrencilerin çalışma alışkanlıkları ve tutumlarının incelenmesi (ilköğretim öğrencileri üzerine bir araştırma) (Master's thesis). Gazi Üniversitesi/Eğitim Bilimleri Enstitüsü, Ankara.

Memiş, A. (2013). A research of the relation between study orientations, gender and school achievement. Life Science Journal, 10(2), 30-38.

Mendezabal, M. J. N. (2013). Study habits and attitudes: the road to academic success. Open science repository education.

Murray, C., \& Wren, C. T. (2003). Cognitive, academic, and attitudinal predictors of the grade point averages of college students with learning disabilities. Journal of Learning Disabilities, 36(5), 407-415. https://doi.org/10.1177/00222194030360050201

Nandhini, M. (2017). Study habits and academic achievement of higher secondary school students in Chennai with respect to their gender and type of school. Research maGma, 1(9), 1-7.

Numan, A., \& Hasan, S.S. (2017). Effect of study habits on test anxiety and academic achievement of undergraduate students. Journal of Research and Reflections in Education, 11(1), 1-14.

Okpala, A., Okpala, C., \& Ellis, R. (2000). Academic efforts and study habits among students in a principles of macroeconomics course. Journal of Education for Business, 75(4), 219-224. https://doi.org/10.1080/08832320009599018 
Onwuegbuzie, A. J., Slate, J. R., \& Schwartz, R.A. (2001). Role of study skills in graduate-level educational research courses. The Journal of Educational Research, 94(4), 238-246. https://doi.org/10.1080/00220670109598757

Orr, F. (1992). Study skills for successful students. Singapore: Allen \& Unvin.

Özakpınar, Y. (2002). Verimli ders çalışmanın psikolojik koşulları. İstanbul: Remzi Kitabevi.

Özbey, N. (2007). Ilköğretim ögrencilerinin ders çalışma alışkanlıklarının bazı değişkenler açısından incelenmesi (Master's thesis). Eskişehir Osmangazi Üniversitesi/Fen Bilimleri Enstitüsü, Eskişehir.

Özsoy, G., Memiş, A., \& Temur, T. (2009). Metacognition, study habits and attitudes. International Electronic Journal of Elementary Education, 2(1), 154-166.

Price, G., \& Maier, P. (2007). Effective study skills. England: Pearson Education Limited.

Rana, S. A., \& Kausar, R. (2011). Comparison of study habits and academic performance of Pakistani British and White British students. Pakistan Journal of Social and Clinical Psychology, 9, 21-26.

Sakirudeen, A. O., \& Sanni, K. B. (2017). Study habits and academic performance of secondary school students in mathematic: a case study of selected secondary schools in Uyo local education council. Research in Pedagogy, 7(2), 283-297. https://doi.org/10.17810/2015.65

Sallabaş, M. E. (2008). İlköğretim 8. sınıf öğrencilerinin okumaya yönelik tutumları ve okuduğunu anlama becerileri arasındaki ilişki. Inönü Üniversitesi Eğitim Fakültesi Dergisi, 9(16), 141-155.

Saraç, S. (2010). İlköğretim beşinci sınıf öğrencilerinin üstbiliş düzeyleri, genel zekâ ve okuduğunu anlama düzeyleri arasındaki ilişkinin incelenmesi (Doctoral Dissertation). Marmara Üniversitesi/Eğitim Bilimleri Enstitüsü, İstanbul.

Schraw, G. (1998). Promoting general metacognitive awareness. Instructional science, 26, $113-125$. https://doi.org/10.1023/A:1003044231033

Singh Y. G. (2011). Academic achievement and study habits of higher secondary students. International Referred Research Journal, 3(27), 19-20.

Smith Rotchford, M. (1984). A study of the relationship of reading achievement and study orientation among a public high school population, a public alternative high school population, and an identified juvenile delinquent population (Doctoral Dissertation). Gonzaga University, Spokane, Washington.

Snodgrass, R. B. (1989). A study of locus-of-control, achievement motivation, and knowledge and use of study skills as factors influencing academic performance in academically talented college students (Doctoral dissertation). The University of Alabama: Tuscaloosa, Alabama.

Şeflek Kovacıoğlu, N. (2006). İlkögrretim ikinci sınıflarında aile çevresi ve çocuğun okumaya karşı tutumu ile okuduğunu anlama becerisi arasındaki ilişkiler (Master's thesis). Yıldız Teknik Üniversitesi/Sosyal Bilimler Enstitüsü, İstanbul.

Şener, K. (2001). İlköğretim öğrencilerinin çalışma alışkanlıklarının matematikteki başarılarına etkileri (Yüksek lisans tezi). Fırat Üniversitesi/Sosyal Bilimler Enstitüsü, Elazı̆̆g. Retrieved from https://tez.yok.gov.tr/Ulusal TezMerkezi/

Tulum, Y. (2001). Hemşirelik öğrencilerinin ders çalışma alışkanlıkları ve tutumları (Master’s thesis). İstanbul Üniversitesi/Sağlık Bilimleri Enstitüsü, İstanbul.

Tunde-Awe, B. M. (2014). Relationship between reading attitudes and reading comprehension performance of secondary school students in Kwara State, Nigeria. Review of Arts and Humanities, 3(2), 203-215.

Turhan, B., \& Zorluel Özer, H. (2017). Metacognitive awareness of reading strategies and academic achievement in reading and writing: a correlational research in an efl context. International Journal of Language Academy, 5(3), 23-34. https://doi.org/10.18033/ijla.3591

Tümkaya, S., \& Bal, L. (2006). Çukurova üniversitesi öğrencilerinin ders çalışma alışkanlıklarının bazı değişkenler açısından incelenmesi. Ç. ̈. Sosyal Bilimler Enstitüsü Dergisi, 15(2), 313-326.

Uluğ, F. (2000). Okulda başarl. İstanbul: Remzi Kitabevi.

Umucu Alpoğuz, D. (2014). Algllanan ana-baba tutumlarının ilkögrretim öğrencilerinin okumaya yönelik tutumlarına ve türkçe dersi akademik başarllarına etkisi (Master's thesis). Ahi Evran Üniversitesi/Sosyal Bilimler Enstitüsü, Kırşehir. https://doi.org/10.16916/aded.92531 
Ürün Karahan, B., \& Taşdan, M. (2016). 5. ve 6. sınıf öğrencilerinin okumaya karşı tutum ve motivasyonlarının okuduğunu anlama becerileri ile ilişkisi. Uluslararası Türkçe Edebiyat Kültür Eğitim Dergisi, 5(2), 949-969. https://doi.org/10.7884/teke.596

Van Kraayenoord, C. E., \& Schneider, W. E. (1999). Reading achievement, metacognition, reading self-concept and interest: A study of German students in Grades 3 and 4. European Journal of Psychology of Education, 14, 305-324. https://doi.org/10.1007/BF03173117

Van Kraayenoord, C. E. (2010). The role of metacognition in reading comprehension. Retrieved from https://www.researchgate.net/publication/46401318_The_role_of_metacognition_in_reading_comprehension

Wonnacott, M. L. H. (1989). Community college student success: the relationship of basic skills, study habits, age, and gender to academic achievement (Doctoral Dissertation). Western Michigan University, Kalamazoo, Michigan.

Yeh, H. (1991). The relationship of academic achievement to the variables of achievement motivation, study habits, intellectual development, and junior college joint entrance examination scores among junior college students in the Republic of China (Doctoral Dissertation). University of Missouri, Columbia (UMI Number: 9123711).

Yıldırım, A., Doğanay, A., \& Türkoğlu, A. (2000). Okulda başarı için ders çalışma ve öğrenme yöntemleri. Ankara: Seçkin.

Yıldız, S. (2015). İlköğretim 6., 7. ve 8. sınıf öğrencilerinin ders çalışma alışkanlıklarının sosyal bilgiler dersi akademik başarısı ile derse karşı tutumu arasındaki ilişki (Master's thesis). Abant İzzet Baysal Üniversitesi/ Eğitim Bilimleri Enstitüsü, Bolu.

Yıldız, M., \& Kaman, Ş. (2016). İlköğretim (2-6. sınıf) öğrencilerinin okuma ve yazma tutumlarının incelenmesi. Türkiye Sosyal Araşttrmalar Dergisi, 2, 507-522.

Yip, M. C. W., \& Chung, O. L. L. (2005). Relationship of study strategies and academic performance in different learning phases of higher education in Hong Kong. Educational Research and Evaluation, 11(1), 61-70. https://doi.org/10.1080/13803610500110414

Yörük, D. (2007). Lise öğrencilerinin akademik başarıları, başarı korkuları ve verimli ders çalışma alışkanlıkları arasındaki ilişkilerin incelenmesi (Master’s thesis). Gazi Üniversitesi/Eğitim Bilimleri Enstitüsü, Ankara. 